\title{
EFFECT OF DRILLING PARAMETERS ON THRUST FORCE AND TORQUE DURING DRILLING OF ALUMINIUM 6061 ALLOY - BASED ON TAGUCHI DESIGN OF EXPERIMENTS
}

\author{
* Reddy Sreenivasulu ${ }^{1}$, Chalamalasetti Srinivasa Rao ${ }^{2}$ \\ ${ }^{1}$ Dept. of Mechanical Engineering, R.V.R. \& J.C.College of Engineering (A), \\ Chowdavaram, Guntur, Andhra Pradesh, India. \\ ${ }^{2}$ Dept. of Mechanical Engineering, University College of Engineering (A), \\ Andhra University, Visakhapatnam, Andhra Pradesh, India. \\ *Corresponding email: rslu1431@gmail.com,csr_auce@yahoo.co.in
}

\begin{abstract}
Hole generating process with drill bit called as drilling, which is very important because large portion of overall machining of any component in production industry needs assemble of parts to make a final shape with rivets and fasteners. It is well known that the drill point geometry has a significant effect on thrust force exerted by a drill bit while drilling. In this study, experimentally investigate the influence of drilling parameters such as point angle, clearance angle, cutting speed, feed rate and drill diameter on the thrust force and torque in drilling. Drilling experiments have been conducted over a wide a range of machining conditions such as cutting speed varied in the range $500 \mathrm{rpm}$ to $1000 \mathrm{rpm}$ in 3steps, feed rate varied from 0.3 to $0.6 \mathrm{~mm} / \mathrm{min}$ in three steps using two flutes uncoated conventional twist drills of three different diameters $(8,10$ and $12 \mathrm{~mm})$ with $118^{0}$ point and $45^{0}$ helix angles. Drill bits tool geometry altered by tool\&cutter grinder and obtained $110^{\circ}, 100^{\circ}$ point angles also clearance angles varied by $4^{0}, 6^{0}$ and $8^{0}$. Holes are performed on Aluminium 6061 alloy material of rectangular cross section having dimensions 300mmx50mmx10mm as per taguchi technique. A kistler (type 9272), four components drill tool dynamometer was used to measure thrust force (Th) and torque (M) exerted by the drill bit during hole making on a work material further the signal was processed to a computer by a multichannel signal amplifier (Kistler 5070 type) was used to record the thrust force and torque. Finally, ANOVA test have been carried out to confirm the significance of factors considered during drilling and compare the predicted values with the experimental values on influence of factors on responses.
\end{abstract}

Key Words: Al 6061 alloy, Thrust Force, Torque, Taguchi-Design of Experiment

\section{INTRODUCTION}

In general, the drilling performance measured includes thrust force, torque and surface quality. Each of these measures is affected by various factors and variables such as the tool and work piece materials properties, the tool geometry, the cutting conditions, cutting fluid and machine tool. Also this chapter separately reviews what has been done in the past in the area of drilling parameters to optimize surface roughness, thrust force and torque.

\section{LITERATURE REVIEW}

J.S. Strenkowski et $\mathrm{al}^{1}$ focused on development of FEM for oblique cutting by taking forces and moments acting on drill, which was based on visco elastic effects on drill bit geometry for oblique sections. An analytical model for oblique cutting was described to analyze a single section in the cutting lip region of the drill bit. S. Madhavan et $\mathrm{al}^{2}$ conducted drilling experiments on GFRP material using taguchi design of experiments, but they concentrated on the effect of delamination factor by varying the cutting speed, feed rate, thrust force and torque during drilling operation. R. Vimal Sam Singh et $\mathrm{al}^{3}$ developed a fuzzy logic based model for forecasting thrust force and torque during drilling, but not considered the changes on geometry of drill. P. V. Gopal Krishna et $\mathrm{al}^{4}$ concentrated their experiments on friction drilling which is unconventional drilling process in which a cone type rotating tool penetrate into material and generate a hole, without generating chips. Aluminum (AA6351) is taken as work material and friction drilling is carried out by hss conical rotating tool, finally they developed mathematical models for axial thrust force and torque. M. Pirtini et $\mathrm{al}^{5}$ considered principles of mechanics to develop mathematical models in drilling to predict cutting forces and surface finish of a hole. This model is able to simulate the cutting forces for various machining conditions in the process in order to obtain drilled profiles. Therefore, in addition to predict the forces, the new model allows finding and visualization of drilled hole shapes in 3D. M Sundeep et $\mathrm{al}^{6}$ investigated experimentally on drilling behavior of

Journal of Mechanical Engineering, Vol. ME 46, December 2016

Transaction of the Mechanical Engineering Division, The Institution of Engineers, Bangladesh 
AISI 316 and attempt made to optimize the process parameters using taguchi design of experiments method. The process parameters of spindle speed, feed rate and drill diameter are affected by thrust and torque during drilling operations. B.Suresh kumar et $\mathrm{al}^{7}$ reveals the conclusions after conducting experiments on drilling operation by using computer numerical control and conventional machines on titanium alloy; the conventional drilling machine produces higher vibrations than computer numerical control machines. The higher spindle speed with lower feed rate generates lower frequency in conventional drilling machine. But in CNC the higher spindle speed with higher feed rate produces the lower frequency. Comparatively $\mathrm{CNC}$ machine create higher thrust force and torque due to its strength and stiffness. Conventional machines acquire higher machining time at lower spindle speed with lower feed rate than $\mathrm{CNC}$ machine. Similarly $\mathrm{CNC}$ machines consume higher machining time at higher spindle speed with lower feed rate. M.Vijaya Kumar et $\mathrm{al}^{8}$, presented in their paper, effect of drilling parameters of AMMC to minimize the thrust force, temperature and surface finish using DFA method. Naseer Ahmed ${ }^{9}$ applied a three dimensional thermo mechanically coupled finite element model of drilling process of AISI 2080 to study the effect of cutting parameter on thrust force and torque. For this experiments are performed to validate the results from simulations. A three dimensional thermo mechanically couple finite element close-to-real model of drilling process was developed to study the effect of variation in the cutting parameters on the thrust forces and torque inside the drill bit, finally concluded that the thrust force increased with increasing the cutting speed and feedrate. Vaishak $\mathrm{N} \mathrm{L}$ et al ${ }^{10}$ put their efforts to understand the effect of parameters like thrust force and torque that are generated during drilling of granite particulate reinforced epoxy composite. The results said that cutting speed and feed rates are influenced more on induced damage in drilling. S. Prakash et $\mathrm{al}^{11}$ conducted experimental study drilling operation towards medium density fibre (MDF) board. They focussed on to the study of various drilling parameters such as feed rate, spindle speed, drill diameter and board thickness on the thrust force generated during drilling.

\section{EXPERIMENTAL PROCEDURE \\ Material and its composition}

Aluminium 6061 alloy material of rectangular cross section of $300 \mathrm{~mm} \times 50 \mathrm{~mm} \times 10 \mathrm{~mm}$ size is used to conduct experiments. The composition of Alluminium alloy 6061 consists of $0.63 \%$ Silicon, $0.096 \%$ Copper, $0.091 \%$ Zinc, $\quad 0.466 \%$ Iron, $0.179 \%$ Manganese, $0.53 \%$ Magnesium, $0.028 \%$ Titanium, $0.028 \%$ Chromium, and remaining alluminum.

\section{Tools and Equipment}

In this study, the experiments were carried out on a radial drilling machine (Make: Siddapura Machine Tools, Gujarat, INDIA) to perform different size of holes on Al 6061 alloy work piece. The drill tools used were HSS-R (DIN 338) twist drill bits made by Bosch Company and commercially available with diameters of 8,10 and $12 \mathrm{~mm}$ with $118^{\circ}$ point angle and $45^{\circ}$ helix angle. Drill bits tool geometry altered by tool\&cutter grinder, obtained $110^{\circ}$ and $100^{\circ}$ point and $4^{0}, 6^{0}$ and $8^{0}$ clearance angles. Kistler type 9272(Kistler Instrumente AG, CH8408, Winterthur, Switzerland make) four components $\left(\mathrm{F}_{\mathrm{X}}, \mathrm{F}_{\mathrm{Y}}, \mathrm{F}_{\mathrm{Z}}\right.$ and $\left.\mathrm{T}\right)$ dynamometer was used to measure thrust force (Th) and torque (M) and the signal was processed to the computer by a type 5070 multichannel signal amplifier (shown in Fig.1).
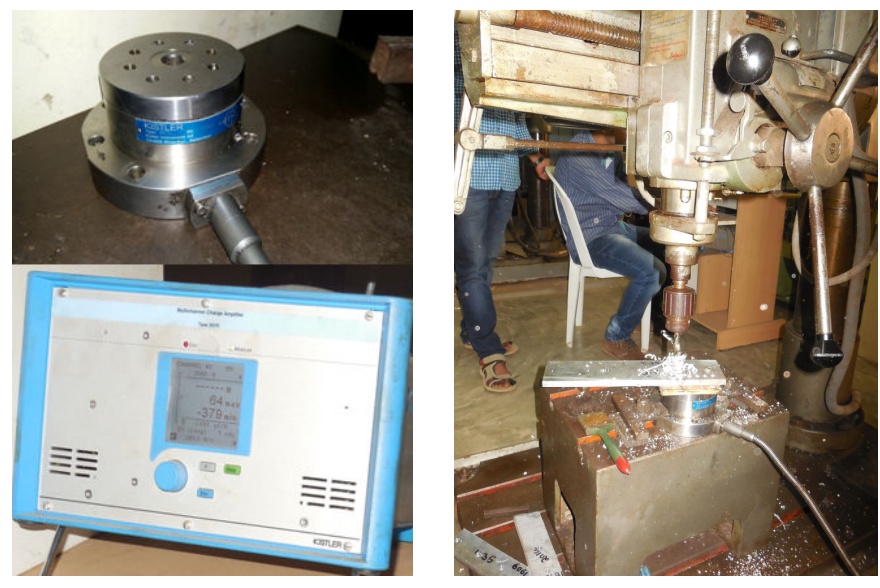

Figure 1. Kistler dynamometer type 9272 (Kistler Instrumente AG, CH8408 Winterthur, Switzerland), Multichannel signal amplifier (kistler type 5070) and radial drilling machine (Make: Siddapura Machine Tools, Gujarat, INDIA).

Journal of Mechanical Engineering, Vol. ME 46, December 2016

Transaction of the Mechanical Engineering Division, The Institution of Engineers, Bangladesh 


\section{EXPERIMENTAL PARAMETERS AND DESIGN}

An experimental plan based on taguchi method ${ }^{12}$ has been considered to get the experimental and response data. In this connection, an orthogonal arrays, signal to noise $(\mathrm{S} / \mathrm{N})$ ratios and analysis of variance (ANOVA) were involved to test the influential parameters on drilling of Aluminium 6061 alloy using HSS twist drill bits. The complete procedure in taguchi design method can be divided into three phases: system design phase, parameter design phase, and tolerance design phase. Out of the three design phases, the second phase - the parameter design phase, is the most important stage. Taguchi's orthogonal array gives a combination of wellstabilized experiments with less number of experiments to be conduct, and signal-to-noise ratio $(\mathrm{S} / \mathrm{N})$, which is logarithmic functions of required output in the process optimization. The signal-tonoise ratio is the ratio of the mean (signal) to the standard deviation (noise). Factors and their levels of the experiments are shown in table1. Experimental plan and responses are depicted in table 2.

Table1: Process parameters and levels of the Experiment

\begin{tabular}{|c|c|c|c|c|c|}
\hline \multirow{2}{*}{ Levels } & \multicolumn{5}{|c|}{ Factors } \\
\cline { 2 - 6 } & Cutting & Feed Rate & Drill & Point & Clearance \\
& Speed $(\mathrm{rpm})$ & $(\mathrm{mm} / \mathrm{min})$ & Diameter $(\mathrm{mm})$ & Angle $\left({ }^{0}\right)$ & Angle $\left({ }^{\circ}\right)$ \\
\cline { 2 - 6 } & CS & FR & D & PA & CA \\
\hline $\mathbf{1}$ & 600 & 0.3 & 8 & $118^{0}$ & $4^{0}$ \\
\hline $\mathbf{2}$ & 800 & 0.5 & 10 & $110^{0}$ & $6^{0}$ \\
\hline $\mathbf{3}$ & 1000 & 0.6 & 12 & $100^{0}$ & $8^{0}$ \\
\hline
\end{tabular}

Table 2: Experimental runs and responses

\begin{tabular}{|c|c|c|c|c|c|c|c|c|}
\hline $\mathrm{R}$ & \multicolumn{7}{|c|}{ Taguchi experimental design table } & \multirow{4}{*}{$\begin{array}{c}\mathrm{S} / \mathrm{N} \\
\text { Ratio } \\
(\beta)\end{array}$} \\
\hline $\mathrm{U}$ & \multicolumn{5}{|c|}{ Choosen Parameters } & \multicolumn{2}{|c|}{ Meseared Responses } & \\
\hline $\mathrm{S}$ & $\begin{array}{l}\text { Cutting } \\
\text { Speed } \\
\text { (rpm) }\end{array}$ & $\begin{array}{c}\text { Feed } \\
\text { Rate } \\
\left(\begin{array}{c}\mathrm{mm} / \mathrm{mi} \\
\mathrm{n})\end{array}\right.\end{array}$ & $\begin{array}{c}\text { Drill } \\
\text { Diameter } \\
(\mathrm{mm})\end{array}$ & $\begin{array}{l}\text { Point } \\
\text { Angle } \\
\text { (Degrees) }\end{array}$ & $\begin{array}{c}\text { Clearance } \\
\text { Angle } \\
\text { (Degrees) }\end{array}$ & $\begin{array}{l}\text { Thrust } \\
\text { Force } \\
\text { (Kgf) }\end{array}$ & $\begin{array}{l}\text { Torque } \\
\text { (Kgm) }\end{array}$ & \\
\hline & $\mathrm{CS}$ & FR & $\mathrm{D}$ & PA & $\mathrm{CA}$ & Th & $\mathrm{M}$ & \\
\hline 1 & 1 & 1 & 1 & 1 & 1 & 108.36 & 272 & -1.6278 \\
\hline 2 & 1 & 1 & 1 & 1 & 2 & 119.21 & 352 & 4.4320 \\
\hline 3 & 1 & 1 & 1 & 1 & 3 & 127.00 & 380 & -7.0672 \\
\hline 4 & 1 & 2 & 2 & 2 & 1 & 124.00 & 456 & 3.7360 \\
\hline 5 & 1 & 2 & 2 & 2 & 2 & 223.00 & 482 & -4.5433 \\
\hline 6 & 1 & 2 & 2 & 2 & 3 & 241.00 & 431 & -5.4292 \\
\hline 7 & 1 & 3 & 3 & 3 & 1 & 328.00 & 340 & -6.1495 \\
\hline 8 & 1 & 3 & 3 & 3 & 2 & 127.00 & 276 & -4.8008 \\
\hline 9 & 1 & 3 & 3 & 3 & 3 & 225.00 & 232 & -1.2765 \\
\hline 10 & 2 & 1 & 2 & 3 & 1 & 329.68 & 308 & -4.4935 \\
\hline 11 & 2 & 1 & 2 & 3 & 2 & 331.00 & 420 & -1.0965 \\
\hline 12 & 2 & 1 & 2 & 3 & 3 & 226.42 & 341 & 4.9026 \\
\hline
\end{tabular}




\begin{tabular}{|c|c|c|c|c|c|c|c|c|}
\hline 13 & 2 & 2 & 3 & 1 & 1 & 218.52 & 367 & -4.2749 \\
\hline 14 & 2 & 2 & 3 & 1 & 2 & 293.00 & 448 & -5.1270 \\
\hline 15 & 2 & 2 & 3 & 1 & 3 & 303.46 & 268 & 2.0188 \\
\hline 16 & 2 & 3 & 1 & 2 & 1 & 367.00 & 403 & -5.0137 \\
\hline 17 & 2 & 3 & 1 & 2 & 2 & 315.00 & 246 & -1.8190 \\
\hline 18 & 2 & 3 & 1 & 2 & 3 & 296.00 & 372 & -6.8348 \\
\hline 19 & 3 & 1 & 3 & 2 & 1 & 125.81 & 384 & -3.2417 \\
\hline 20 & 3 & 1 & 3 & 2 & 2 & 127.80 & 364 & -3.3032 \\
\hline 21 & 3 & 1 & 3 & 2 & 3 & 224.00 & 388 & -4.6847 \\
\hline 22 & 3 & 2 & 1 & 3 & 1 & 122.00 & 454 & -3.8870 \\
\hline 23 & 3 & 2 & 1 & 3 & 2 & 302.00 & 374 & -3.6437 \\
\hline 24 & 3 & 2 & 1 & 3 & 3 & 268.74 & 358 & 1.5171 \\
\hline 25 & 3 & 3 & 2 & 1 & 1 & 217.32 & 207 & -2.7075 \\
\hline 26 & 3 & 3 & 2 & 1 & 2 & 340.00 & 282 & -4.7936 \\
\hline 27 & 3 & 3 & 2 & 1 & 3 & 233.00 & 278 & -5.1176 \\
\hline
\end{tabular}

\section{ANALYSIS OF S/N RATIO}

In the taguchi design method, the term 'signal' represents the required value (mean) for the output response and the term 'noise' represents the undesirable value (standard deviation) for the output response. $\mathrm{S} / \mathrm{N}$ ratio used to measure the quality characteristic deviating from the desired value. The $\mathrm{S} / \mathrm{N}$ ratio is defined as $\beta=-10 \log$ (M.S.D), Where M.S.D is the mean square deviation for the output characteristic. The $\mathrm{S} / \mathrm{N}$ ratio table for observed responses is shown in Table 3.

Table 3. S/N Ratio for Smaller is better

\begin{tabular}{|c|c|c|c|c|c|}
\hline Level & $\begin{array}{c}\text { Cutting Speed } \\
(\mathrm{rpm}) \mathrm{CS}\end{array}$ & $\begin{array}{c}\text { Feed Rate } \\
(\mathrm{mm} / \mathrm{min}) \mathrm{FR}\end{array}$ & $\begin{array}{c}\text { Drill Diameter }(\mathrm{mm}) \\
\mathrm{D}\end{array}$ & $\begin{array}{c}\text { Point angle }\left(^{\circ}\right) \\
\text { PA }\end{array}$ & $\begin{array}{c}\text { Clearance angle }\left(^{\circ}\right) \\
\text { CA }\end{array}$ \\
\hline 1 & -2.525 & $\mathbf{- 1 . 7 9 7}$ & -2.660 & $\mathbf{- 2 . 1 0 3}$ & $\mathbf{- 2 . 4 4 1}$ \\
\hline 2 & $\mathbf{- 2 . 4 1 5}$ & -2.181 & $\mathbf{- 2 . 1 7 1}$ & -3.459 & -2.743 \\
\hline 3 & -3.318 & -4.279 & -3.426 & -2.696 & -3.073 \\
\hline Delta & 0.902 & 2.481 & 1.255 & 1.356 & 0.632 \\
\hline Rank & 4 & 1 & 3 & 2 & 5 \\
\hline
\end{tabular}

\section{DISCUSSION ON RESULTS}

From normal probability plots were obtained by residual vs percentage deposition of experimental responses with $95 \%$ confidence level for thrust force and torque as shown in Fig.2 \& Fig.3.

From Table 3, it is observed that feed rate, point angle, drill diameter, cutting speed and clearance angle has the order of influence on thrust force and torque during drilling of Al6061 alloy. The optimum parameters combination thrust force and torque are CS2FR1D2PA1CA1 corresponding to the largest values of $\mathrm{S} / \mathrm{N}$ ratio for all control parameters.
From figure.4 main effects plots for means of thrust force and torque and for the combination of parameters individual rankwise are CS2FR3D 3PA3CA2 and CS3FR3D3PA2CA1, respectively.

From Figure 5 interaction plot, which shows individual parameter influence over the thrust force and torque during the drilling operation. 


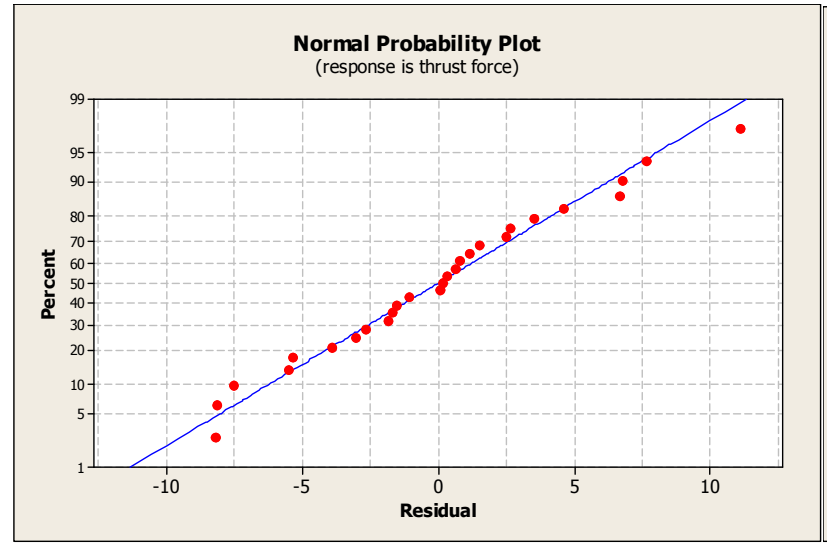

Figure 2. Normal probability plots for thrust force

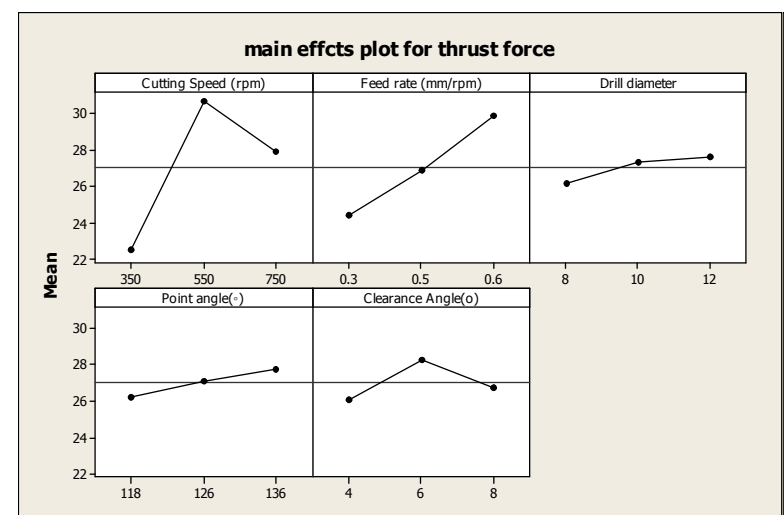

Figure 4. Response graphs for thrust force and torque

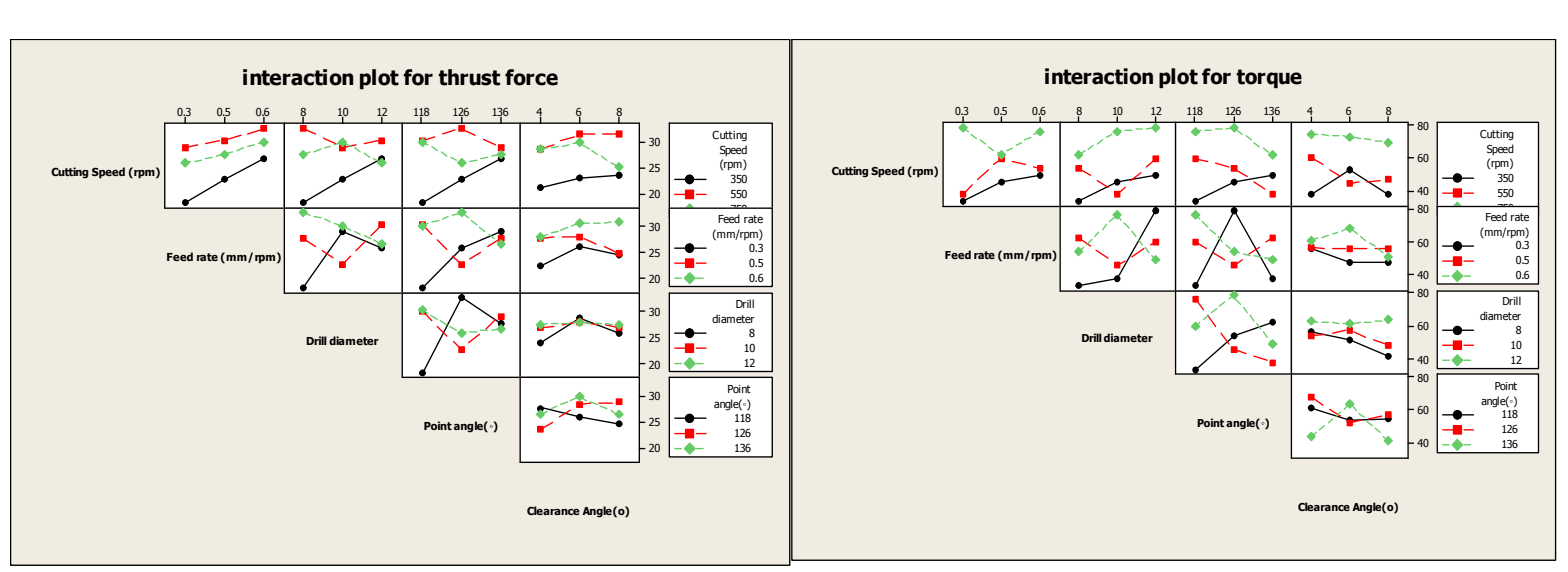

Figure 5. Interaction plot for thrust force and torque

\section{Analysis of Varience (ANOVA) test for confirmation}

The purpose ANOVA is to investigate, the significance of factors choosen in the beginning of experimentation because the factors are considered basically from experience or literature but in actual

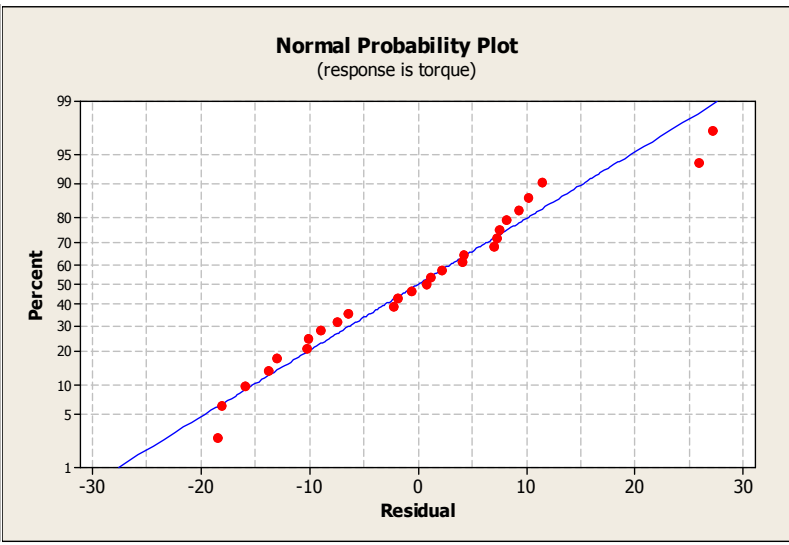

Figure 3. Normal probability plots for torque

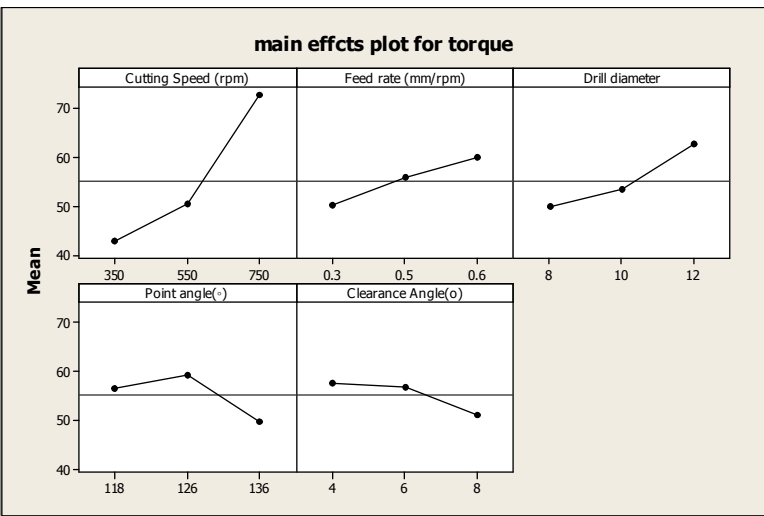

practice some of these factors may or may not be influence, so it will be known after ANOVA test.

Table 4 shows the results of ANOVA for thrust force, cutting speed, feed rate, drill diameter, and point angle are the more significant factors for the thrust force. 
Table 5 shows the results of ANOVA for torque, cutting speed, feed rate, drill diameter, point angle and clearance angle are the significant factors for the torque.

Table 4: ANOVA for thrust force (Th)

\begin{tabular}{|l|l|l|l|l|l|}
\hline Factors & DOF & SS & MS & F & \\
\hline $\begin{array}{l}\text { Cutting } \\
\text { speed }\end{array}$ & 2 & 0.00871 & 0.00435 & 36.25 & significant \\
\hline Feed rate & 2 & 0.00292 & 0.00146 & 12.16 & significant \\
\hline $\begin{array}{l}\text { Drill } \\
\text { diameter }\end{array}$ & 2 & 0.00218 & 0.00109 & 9.08 & significant \\
\hline Point angle & 2 & 0.00684 & 0.00342 & 28.5 & significant \\
\hline $\begin{array}{l}\text { Clearance } \\
\text { angle }\end{array}$ & 2 & 0.00140 & 0.00070 & 2.83 & In significant \\
\hline Error & 16 & 0.001926 & 0.00012 & & \\
\hline Total & 26 & 0.023976 & & & \\
\hline
\end{tabular}

$F$ table at $95 \%$ confidence level is $F_{0.05,2,16}=3.63, F$ exp $\geq F$ table

Table 5: ANOVA for torque (M)

\begin{tabular}{|l|l|l|l|l|l|}
\hline Factors & DOF & SS & MS & F & \\
\hline Cutting speed & 2 & 0.0066 & 0.0033 & 16.75 & significant \\
\hline Feed rate & 2 & 0.0027 & 0.0013 & 6.598 & significant \\
\hline Drill diameter & 5 & 0.0029 & 0.0015 & 7.614 & significant \\
\hline Point angle & 2 & 0.00702 & 0.00351 & 17.766 & significant \\
\hline $\begin{array}{l}\text { Clearance } \\
\text { angle }\end{array}$ & 2 & 0.0053 & 0.0027 & 13.705 & significant \\
\hline Error & 16 & 0.00315 & 0.000197 & & \\
\hline Total & 26 & 0.02765 & & & \\
\hline
\end{tabular}

Significant, $F$ table at $95 \%$ confidence level is $F_{0.05,2,16}=3.63, F_{\text {exp }} \geq F$ table 
Table 6. Optimal values of individual machining characteristics

\begin{tabular}{|l|l|l|l|l|}
\hline $\begin{array}{l}\text { machining } \\
\text { characteristics }\end{array}$ & $\begin{array}{l}\text { Optimal } \\
\text { combination of } \\
\text { parameters }\end{array}$ & $\begin{array}{l}\text { Significant } \\
\text { parameters(at 95\% } \\
\text { confidence level) }\end{array}$ & $\begin{array}{l}\text { Predicted } \\
\text { optimum value }\end{array}$ & Experimental value \\
\hline Thrust force(Th) & CS2FR3D3PA3CA2 & CS,FR,D,PA & $98.43 \mathrm{Kgf}$ & $108.36 \mathrm{Kgf}$ \\
\hline Torque (M) & CS3FR3D3PA2CA1 & CS,FR,D,PA,CA & $197.87 \mathrm{Kgm}$ & $207.27 \mathrm{Kgm}$ \\
\hline
\end{tabular}

Confirmatory experiments were conducted for thrust force and torque, corresponding their optimal setting of process parameters to validate the used approach, obtained the values of $98.43 \mathrm{Kgf}, 197.87 \mathrm{Kgm}$ for thrust force and torque respectively. Predicted and experimental values of responses are depicted in table 6.

\section{CONCLUSIONS}

The taguchi design of experiments method was a way of optimizing the process parameters in drilling for A16061alloy.

From response table of $\mathrm{S} / \mathrm{N}$ ratio, it is observed that feed rate, point angle, drill diameter, cutting speed and clearance angle has the order of influence on thrust force and torque during drilling of Al 6061 alloy. The largest values of $\mathrm{S} / \mathrm{N}$ ratio for all controllable factors. It is the recommended levels of the controllable parameters for the process of drilling as the minimization of thrust force and torque.

The result of ANOVA for thrust force, cutting speed and point angle are more significant parameters for affecting both the thrust force and torque in an order.

The optimal setting of process parameters to validate thrust force and torque are CS2FR3D3PA3CA2 and CS3FR3D3PA2CA1 respectively, obtained the values of $108.36 \mathrm{Kgf}$, 207.27 Kgm respectively. Percentage improvement between the experimental and optimal setting of parameters after conformation test conducted by choosing significant factors from ANOVA are $9.16 \%$ in thrust force and $4.53 \%$ in torque.

\section{REFERENCES:}

1. J.S. Strenkowski, C.C. Hsieh, A.J. Shih , An analytical finite element technique for predicting thrust force and torque in drilling, International Journal of Machine Tools \& Manufacture (2004) $1413-1421$

2. S. Madhavan, T. Lakshmi Narayanan, K.A. Anant, and Sathappan, Influence of Thrust, Torque Responsible for Delamination in drilling of Glass Fabric - Epoxy / Rigid polyurethane foam sandwich hybrid composite, Proceedings of International
Conference on Advances in Mechanical Engineering 2010, pp73- 77, DOI: 02.AMAE.2010.01.63

3. R. Vimal Sam Singh, B.Latha, and V.S.Senthilkumar, Modeling and Analysis of Thrust Force and Torque in Drilling GFRP Composites by Multi-Facet Drill Using Fuzzy Logic, International Journal of Recent Trends in Engineering, Vol. 1, No. 5, May 2009, pp 66-70, ACADEMY PUBLISHER.

4. P. V. Gopal Krishna, K. Kishore and V. V. Satyanarayana, some investigations in friction drilling AA6351 using high speed steel tools, ARPN Journal of Engineering and Applied Sciences, VOL. 5, NO. 3, March 2010, pp 11-15

5. M. Pirtini, I. Lazoglu, Forces and hole quality in drilling, International Journal of Machine Tools \& Manufacture 45 (2005) 1271-1281

6. M Sundeep, M Sudhahar, T M Kannan, P Vijaya Kumar and $\mathrm{N}$ Parthipan,Optimization of drilling parameters on austenitic stainless steel (AISI 316) using taguchi's methodology, Int. J. Mech. Eng. \& Rob. Res. Vol. 3, No. 4, pp 388-394, October, 2014.

7. B.Suresh kumar , N. Bskar, Experimental Investigation of Machining Parameters in Drilling Operation Using Conventional and CNC Machines on Titanium Alloy International Journal of Engineering and Technology Vol 6 No 2, pp 872880, Apr-May 2014.

8. M.Vijaya Kumar, P.Venkataramaiah, Selection of optimal parameters in drilling of aluminium metal matrix composites using desirable-fuzzy approach, Mechanica Confab, Vol. 2, No. 5, pp14-27, AugustSeptember 2013.

9.Naseer Ahmed, Effect of Changing Drilling Parameters on Thrust Force and Torque, Middle-East Journal of Scientific Research 21 (2),pp 347-352, 2014. 
10. Vaishak N L, Ramakrishna Devananda, Jaimon D. Quadros, Rakshith Shetty and S. S. Balakrishna, Analysis of Thrust Force and Torque in Drilling Granite particulate Reinforced Epoxy Composites by using Multi Facet HSS Twist Drill, Proceedings of 8th International Conference on Engineering and Technology Research 24 - 25 April 2014, Novotel World Trade Centre, Dubai, UAE, ISBN: 978-1922069-49-8

11. S.Prakash, J. lilly mercy, Dhrubajyoti Baruah, Putti Venkata Siva teja, a fuzzy logic model to evaluate thrust force in the drilling of medium density fibre board, $5^{\text {th }}$ International \& 26th All India Manufacturing Technology, Design and Research Conference (AIMTDR 2014) December 12th-14th, 2014, IIT Guwahati, Assam, India.

12. D.C. Montgomery "Design and analysis of experiments", John Wiley and Sons, New York, 2001. 